\title{
Ultrastructural localization of antigenic determinants conserved during Perkinsus atlanticus trophozoite to prezoosporangium differentiation
}

\author{
Juan F. Montes*, Mercè Durfort, José García-Valero \\ Departament de Biologia Cel-lular, Facultat de Biologia, Universitat de Barcelona, Avda. Diagonal, 645, \\ 08028 Barcelona, Spain \\ Centre de Referència de Recerca i Desenvolupament en Aqüicultura (CRAq) de la Generalitat de Catalunya
}

\begin{abstract}
Trophozoite, prezoosporangium and zoospore are the 3 main developmental stages that form the life cycle of protozoa of the genus Perkinsus. Several studies have shown that the differentiation of Perkinsus species from the trophozoite to the prezoosporangium stage involves a substantial modification of the antigenic characteristics of these molluscan parasites. With the aim of determining the presence and distribution of antigenic determinants conserved during trophozoite to prezoosporangium differentiation, a polyclonal serum was raised against trophozoites of $P$. atlanticus purified from parasitized gills of the clam Tapes semidecussatus. Immunocytochemical analyses showed that the serum generated against $P$. atlanticus trophozoites strongly cross-reacted with the prezoosporangium stage. Immunogold electron microscopy studies revealed that the granular component of the nucleolus, chromatin, cell wall, plasmalemma, lomasomes and vacuolar membrane are the main subcellular structures where the immunodominant epitopes consistently expressed by trophozoites and prezoosporangia are located. Furthermore, analysis of the immunogold staining pattern revealed that the labelling density obtained for prezoosporangia in the nucleolus, cell wall, plasmalemma and lomasomes was significantly higher than that obtained for trophozoites. The most immunoreactive structure in trophozoites was the granular component of the nucleolus, whereas in prezoosporangia it was the lomasome. Interestingly, the main antigenic compartment of $P$. atlanticus, considering both developmental stages, was the lomasome of the prezoosporangium. These findings show that $P$. atlanticus trophozoite to prezoosporangium differentiation is accompanied by significant qualitative and quantitative changes in the ultrastructural distribution of the immunodominant antigens shared by these 2 developmental stages.
\end{abstract}

KEY WORDS: Perkinsus atlanticus - Protozoan parasite - Tapes semidecussatus - Clam disease · Antigenic cross-reactivity $\cdot$ Lomasomes $\cdot$ Electron microscopy $\cdot$ Immunocytochemistry

\section{INTRODUCTION}

Protozoa of the genus Perkinsus - $P$. marinus (Mackin et al. 1950), P. olseni (Lester \& Davis 1981), P. atlanticus (Azevedo 1989), P. qugwadi (Blackbourn et al. 1998), P. chesapeaki (McLaughlin et al. 2000), $P$. andrewsi (Coss et al. 2001) and P. mediterraneus (Casas et al. 2004) - are serious pathogens with highly destructive potential in bivalves and gas- tropods worldwide (reviewed by Villalba et al. 2004). At present, Perkinsus species are placed within the newly established phylum Perkinsozoa (Norén et al. 1999), bridging the groups Apicomplexa and Dinoflagellata in which Perkinsus was previously included (Levine 1978, Siddall et al. 1997). Recent phylogenetic studies reveal that Perkinsus is a key organism for understanding early alveolate evolution (Saldarriaga et al. 2003, Leander \& Keeling 2004). 
On the Atlantic and Mediterranean coasts of Europe, parasitism by Perkinsus atlanticus has been associated with epizootic outbreaks involving large-scale mortalities of commercially valuable venerid clams of the genus Tapes (= Ruditapes $=$ Venerupis $)$, such as the indigenous species T. decussatus (Da Ros \& Canzonier 1985, Comps \& Chagot 1987, Azevedo 1989, Figueras et al. 1992, Villalba et al. 1993, Santmartí et al. 1995) and the introduced species $T$. semidecussatus $(=T$. philippinarum = T. japonica) (Sagristà et al. 1991, Santmartí et al. 1995). Moreover, recent mass mortalities of T. semidecussatus reported from Japanese and Korean waters have also been attributed to a $P$. atlanticus-like organism (Lee et al. 2001, Park \& Choi 2001).

Although not fully understood, the life cycle of Perkinsus atlanticus consists of 3 main stages: trophozoite, prezoosporangium (also named hypnospore) and zoospore (Azevedo 1989, Sagristà et al. 1996, Casas et al. 2002). Trophozoites are the vegetative form that proliferates in the connective tissue of the host. During incubation in fluid thioglycollate medium, and probably in dying hosts (AuzouxBordenave et al. 1995), they enlarge substantially and differentiate into prezoosporangia. When this life-cycle form is placed into seawater it releases biflagellated zoospores, which are the main infective stage of this parasite. Our earlier reports showed that the differentiation of $P$. atlanticus from the trophozoite to the prezoosporangium stage involves a substantial modification of the antigenic characteristics of this clam parasite (Montes et al. 1995). However, there are no data regarding the antigenic determinants conserved during $P$. atlanticus trophozoite to prezoosporangium differentiation. Progress towards understanding the life cycle, epidemiology and pathogenesis of $P$. atlanticus can be propelled by the knowledge of these shared epitopes. In the present study, polyclonal antibodies were raised against $P$. atlanticus trophozoites, allowing us to establish the presence and subcellular distribution of common antigenic determinants to trophozoites and prezoosporangia.

\section{MATERIALS AND METHODS}

Clams. Market-sized specimens of Tapes semidecussatus were obtained from different clam beds of the delta of the River Ebro, Tarragona (NE Spain), Mediterranean Sea, an area endemic for Perkinsus atlanticus. Specimens were collected from July to September 2001.

Purification of Perkinsus atlanticus trophozoites. The trophozoites of $P$. atlanticus were purified from isolated parasitized gills following, essentially, the procedure described by López et al. (1997). In 4 independent experiments, a total amount of $642 \mathrm{~g}$ of gills (from approx. $40 \mathrm{~kg}$ of clams) were exhaustively washed with $0.22 \mu \mathrm{m}$ filtered seawater (FSW) of $25 \%$ salinity containing $400 \mathrm{U} \mathrm{ml}^{-1}$ penicillin G (Sigma) and $500 \mu \mathrm{g} \mathrm{ml}^{-1}$ streptomycin sulfate (Sigma). After the bactericide treatment, the isolated gills were chopped with a motorized hand homogenizer in icecold FSW (1 ml per $5 \mathrm{~g}$ gills) containing the following protease inhibitors (PI): 1 mM captopril (Sigma), $1 \mathrm{mM}$ phenylmethylsulphonyl fluoride (PMSF; Boehringer) and $3 \mu \mathrm{M}$ E-64 (Boehringer Mannheim). The resultant tissue suspension was sequentially filtered through nylon meshes of 100, 50 and $20 \mu \mathrm{m}$ and the filtrate centrifuged twice at $500 \times g$ for $15 \mathrm{~min}$. The pellet was resuspended in $0.1 \mathrm{M}$ phosphate-buffered saline (PBS)-PI to half the original volume and $15 \mathrm{ml}$ of the resuspension layered onto $30 \mathrm{ml}$ of $15 \%$ sucrose containing $10 \mathrm{mM}$ EDTA and $0.7 \mathrm{M} \mathrm{NaCl}$. Clarification was carried out at $2500 \times g$ for $30 \mathrm{~min}$, as were all subsequent centrifugations. The resultant pellet was diluted with an equal volume of PBS-PI, $20 \mathrm{ml}$ applied to the top of a 2-step sucrose gradient (15 and $35 \%, 15 \mathrm{ml}$ of each), and centrifuged. The enriched fraction of trophozoites appearing at the gradient interface was fractionated through a discontinuous Percoll (Sigma) density gradient (10, 20, 30, 40 and $50 \% ; 2.5 \mathrm{ml}$ of each) containing $10 \mathrm{mM}$ EDTA and $0.7 \mathrm{M} \mathrm{NaCl}$. After centrifugation, the gradient interfaces were collected, diluted 1:1 with PBSPI and separately washed by sedimentation through a similar volume of $15 \%$ sucrose. All steps were performed at $4^{\circ} \mathrm{C}$. The purity of each fraction $(\mathrm{F})$ was determined by differential interference contrast microscopy. F1 (PBS-PI/10\% Percoll interface) and F2 (10\%/20\% Percoll interface) were used for rabbit immunization.

Immunization and production of antisera. Specific polyclonal antisera against Perkinsus atlanticus trophozoites (PAT) were obtained by immunization of F1 and F2 pooled fractions. In brief, young, white, male New Zealand rabbits, weighing 2 to $3 \mathrm{~kg}$, were immunized 3 times by intramuscular injections at $2 \mathrm{wk}$ intervals with the equivalent of $3.3 \mathrm{mg}$ total protein (1.1 $\left.\mathrm{mg}_{\text {injection }}{ }^{-1}\right)$. Immunizations were performed by emulsion of the immunogen in Freund's adjuvant (Sigma), complete for the first injection and incomplete thereafter. The rabbits were bled prior to the immunizations, and the sera obtained were used for control studies. Each antiserum was tested by means of immunocytochemical techniques using light and electron microscopy.

Immunocytochemistry. For immunofluorescence staining, tissue samples from Tapes semidecussatus were fixed in $2 \%(\mathrm{w} / \mathrm{v})$ paraformaldehyde in PBS 
(pH 7.4) overnight at $4^{\circ} \mathrm{C}$. Specimens were then cryoprotected by infusion with $30 \%$ sucrose in PBS, embedded in optimum-cutting temperature compound (OCT; Miles Laboratories), quickly frozen in dry-ice and stored at $-35^{\circ} \mathrm{C}$. Sections $7 \mu \mathrm{m}$ thick were cut using a cryostat 2800 Frigocut-E (ReichertJung) and thaw-mounted onto gelatin-coated slides. Before labelling, sections were rinsed twice with $0.1 \mathrm{M}$ glycine in PBS (gly PBS) for $10 \mathrm{~min}$ and treated with $2 \%$ ovalbumin in PBS for $30 \mathrm{~min}$. The sections were then incubated with the serum against PAT (1:500) for $2 \mathrm{~h}$ at room temperature and rinsed 3 times with gly PBS for $15 \mathrm{~min}$. Bound polyclonal antibody was visualized following incubation with tetramethylrhodamine-isothiocyanate (TRITC)-conjugated swine anti-rabbit IgG (Dako) for $1 \mathrm{~h}$ at room temperature. After washing in PBS, slides were mounted in Fluoromount G (Electron Microscopy Science).

For immunogold labelling, abscesses from Perkinsus atlanticus-infected gills and isolated prezoosporangia were fixed in $4 \%$ paraformaldehyde, $0.1 \%$ glutaraldehyde in PBS for $2 \mathrm{~h}$ at $4^{\circ} \mathrm{C}$. The prezoosporangia of $P$. atlanticus were purified after culture of parasitized gills from Tapes semidecussatus in fluid thioglycollate medium (FTM; Difco Laboratories), as previously described in detail by Montes et al. (2002). After washing, all samples were processed for Lowicryl K4M infiltration at low temperature according to the manufacturer's specifications (Polysciences). Polymerization was induced by UV irradiation at $-35^{\circ} \mathrm{C}$ for $2 \mathrm{~d}$. Immunogold labelling was essentially performed following the schedule described above. After washing and blocking, the grids were incubated with the serum against PAT (1:1000) and bound polyclonal antibodies were then visualized following incubation with $10 \mathrm{~nm}$ protein A gold (Dr. Slot). Finally, the grids were washed thoroughly in PBS and double-distilled water, and stained with uranyl acetate and Reynold's lead citrate.

Controls were performed by replacing the specific antiserum with matched preimmune serum. Additional controls were carried out by omitting the specific antiserum from the immunolabelling procedure. Thin sections were observed with a ReichertJung Polyvar 2 optical microscope and the ultrathin sections with a Hitachi H-600 AB transmission electron microscope.

Quantitative evaluation. Labelling density was estimated as the number of gold particles either per area of compartment or per unit of membrane length (Griffiths \& Hoppeler 1986, Montes et al. 1996). Both parameters area and length were estimated using stereological methods (Weibel 1979) and significance of mean differences was tested using a Student's $t$-test.

\section{RESULTS}

\section{Immunofluorescence}

When cryostat sections of parasitized Tapes semidecussatus were incubated with the serum against PAT, labelling was exclusively associated with the trophozoites of Perkinsus atlanticus, irrespective of their organic localization. Neither the capsule nor the cellular reaction or other host tissues showed affinity for this antiserum. In addition, no reactivity was observed when the preimmune serum was used as a control (data not shown). This specific antiserum labelled all maturation stages of the parasite, the stained structures being the nucleus, cytoplasm and cell wall (Fig. 1). No significant labelling was detected in the content of the vacuole, the cell compartment characteristic of the mature forms (Fig. 1).

\section{Immunogold labelling}

The reactivity of the serum against PAT was also assayed by immunogold electron microscopy in gill abscesses from Perkinsus atlanticus-infected Tapes semidecussatus. The labelling observed by means of this technique corroborated that obtained by indirect immunofluorescence, since the staining was restricted to the trophozoites of $P$. atlanticus, whereas the host tissues were devoid of labelling. The nucleolus, chromatin, cell wall, plasmalemma, lomasomes and vacuolar membrane were the main parasite structures labelled (Figs. 2 to 5). The lack of labelling after incubation with the preimmune serum (data not shown) confirmed the specificity of this antiserum.

The nucleolus and nucleoplasm were the most intensively labelled trophozoite structures (Table 1), both of

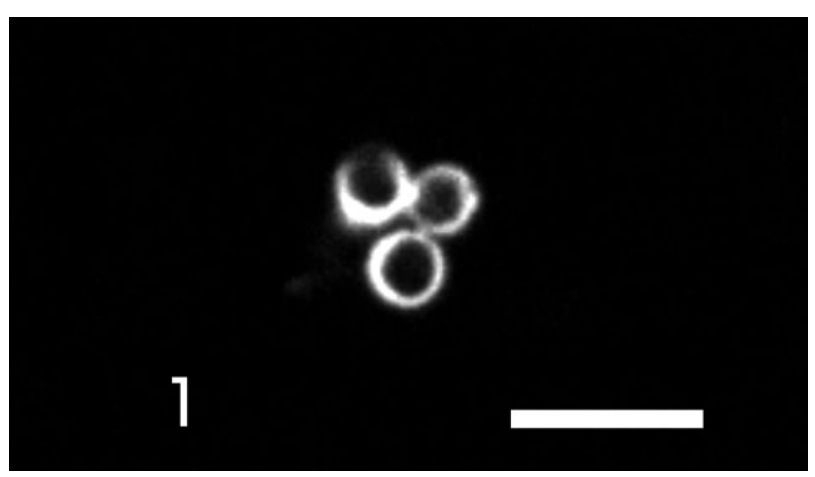

Fig. 1. Perkinsus atlanticus-parasitized gills from Tapes semidecussatus. Immunofluorescence staining of trophozoite compartments that react with the serum against $P$. atlanticus trophozoites (PAT). Staining is associated with the nucleus, cytoplasm and cell wall. Scale bar $=25 \mu \mathrm{m}$ 
them showing strong immunostaining (Fig. 2). In the nucleolus, labelling density was considerably higher than that observed in the nucleoplasm (Table 1), and was primarily restricted to the granular component (Fig. 2). The fibrillar areas of the nucleolus, typified by low electron-density, were devoid of labelling (Fig. 2). In the nucleoplasm, the labelling showed a diffuse pattern, the interchromatin spaces being essentially free of immunoreactivity (Fig. 2). Likewise, no significant labelling was associated with the nuclear envelope.

The immunogold staining of the cell wall was strong and homogeneously distributed (Fig. 3), and no appar-
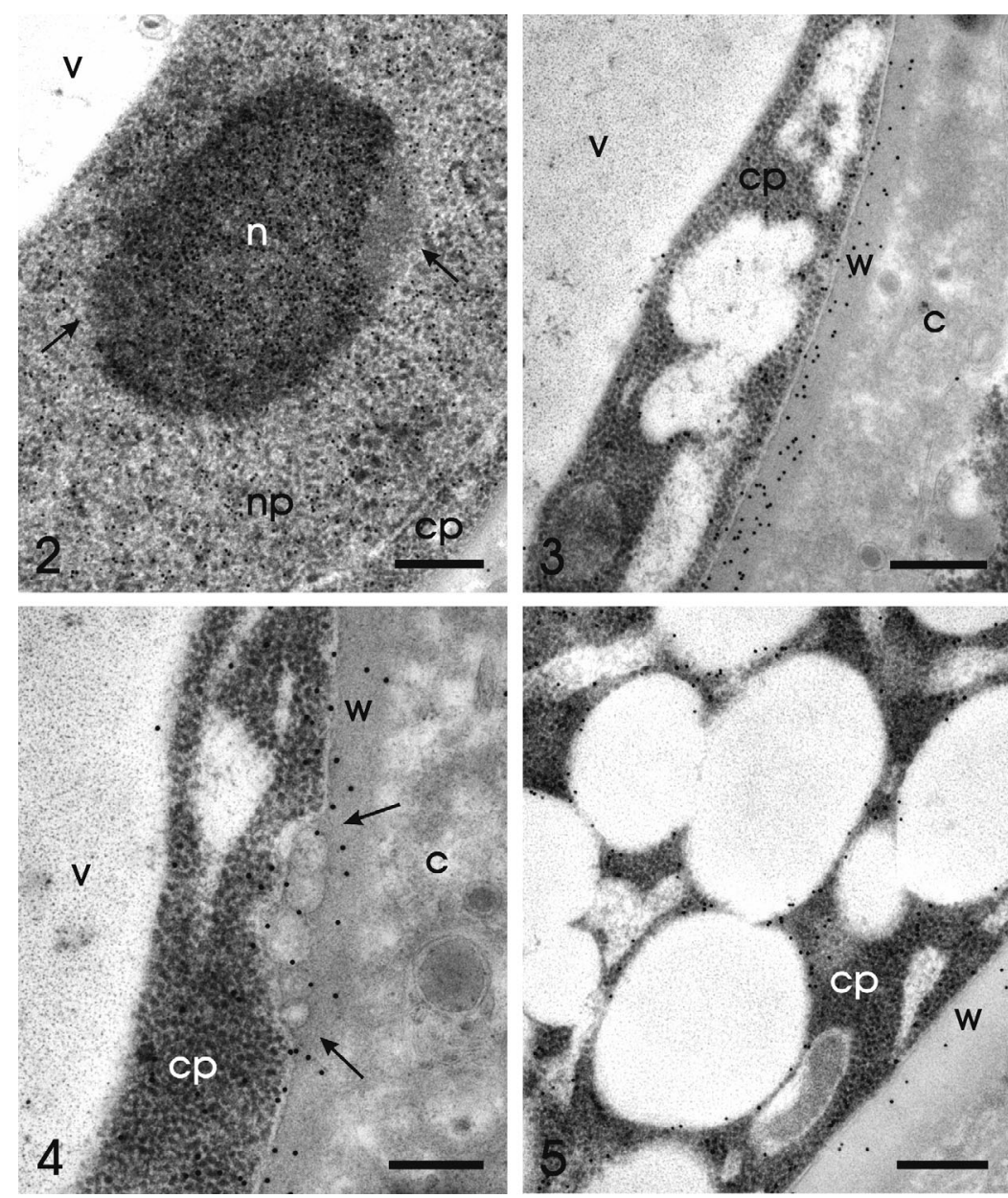

Figs. 2 to 5. Perkinsus atlanticus-parasitized gills from Tapes semidecussatus. Immunogold staining of trophozoite structures that react with the serum against PAT. Fig. 2. Granular component of the nucleolus (n) and the nucleoplasm (np) are the nuclear structures labelled. Both the fibrillar component of the nucleolus (arrows) and the nuclear envelope are unlabelled. $\mathrm{cp}=$ cytoplasm; $\mathrm{v}=$ vacuole; scale bar $=0.3 \mu \mathrm{m}$. Fig. 3. Strong and homogeneous immunostaining of the cell wall $(\mathrm{w}) . \mathrm{c}=$ capsule; $\mathrm{cp}=$ cytoplasm; $\mathrm{v}=$ vacuole; scale bar $=$ $0.3 \mu \mathrm{m}$. Fig. 4. Immunoreactivity of the plasma membrane is weak but uniform. Note that the lomasome, delimited by arrows, shows a similar reactivity. $\mathrm{c}=$ capsule $; \mathrm{cp}=$ cytoplasm; $\mathrm{v}=$ vacuole $; \mathrm{w}=$ cell wall $;$ scale bar $=0.2 \mu \mathrm{m}$. Fig. 5 . Immunostaining of the vacuolar membranes. $\mathrm{cp}=$ cytoplasm $_{i} \mathrm{w}=$ cell $\mathrm{wall}_{;}$ scale bar $=0.3 \mu \mathrm{m}$ ent differences in the labelling pattern were observed etween the different developmental stages of the malemma and the cell wall. Labelling was also related to the vacuolar membrane. This immunostaining was weak but significant (Fig. 5).

When the immunolocalization was carried out in the isolated prezoosporangia, the resultant labelling pattern closely resembled that obtained in the trophozoites, since the nucleolus, chromatin, cell wall, plasmalemma, lomasomes and vacuolar membrane were also the reactive structures here (Figs. 6 to 9). However, considerable differences were detected when labelling densities were compared in homologous compartments from both Perkinsus atlanticus forms (Table 1). Thus, the labelling densities obtained for prezoosporangia in the nucleolus, cell wall (Fig. 6), plasma membrane (Fig. 7) and lomasomes (Figs. 8 \& 9) were significantly higher than the densities obtained for trophozoites. Interestingly, the lomasome was the prezoosporangium structure that showed the strongest immunoreactivity (Table 1).

\section{DISCUSSION}

In the current study, we have obtained, for the first time, a polyclonal serum against Perkinsus atlanticus trophozoites. Results obtained by means of this serum have allowed us to demonstrate that several antibody-binding epitopes are conserved during $P$. atlanticus trophozoite to prezoosporangium differentiation. Furthermore, the subcellular distribution of these antigenic determinants has been established.

Immunocytochemical studies of lifecycle forms of Perkinsus atlanticus showed that the serum generated here against $P$. atlanticus trophozoites strongly cross-reacted with the prezoosporangium stage. These results complement and extend our earlier study in which we reported that the polyclonal antibody developed against $P$. atlanticus prezoosporangia failed to cross-react 
with the trophozoite stage (Montes et al. 1995). Overall, these findings are essentially in agreement with experimental data obtained by others in the oyster parasite $P$. marinus. Indeed, whereas all polyclonal and monoclonal antibodies so far obtained against $P$. marinus trophozoites cross-reacted with the prezoosporangium stage (Gauthier \& Vasta 1995, Romestand et al. 2001), 27 of the 29 antibodies developed against $P$. marinus prezoosporangia did not show crossreactivity with the trophozoite stage (Choi et al. 1991, Dungan \& Roberson 1993, Gauthier \& Vasta 1995, Romestand et al. 2001). Taken together, these results indicate that Perkinsus species exhibit a stage-specific control of protein expression. The fact that the present and previous antibodies developed against Perkinsus trophozoites cross-reacted with the prezoosporangium stage, but not vice versa, strongly suggests that although the main protein pool of Perkinsus prezoosporangia is differentially expressed in this life-cycle form, some antigenic determinants are conserved during trophozoite to prezoosporangium differentiation.

Through the use of immunogold electron microscopy we have determined, for the first time, that the granular component of the nucleolus, chromatin, cell wall, plasmalemma, lomasomes and vacuolar membrane are the main subcellular structures in which the immunodominant epitopes consistently expressed by the 2-walled forms of a Perkinsus species are located. These results confirm and extend the 2 previous studies on this issue. The pioneering work of Dungan \& Roberson (1993) reported, by means of immunofluorescence techniques, that the antibodybinding epitopes shared by trophozoites and prezoosporangia of $P$. marinus are associated with the plasma membrane and with nuclear and cytoplasmic elements. Moreover, our recent study examining the composition of the cell wall of $P$. atlanticus showed that PWP-1, the main proteinaceous component of the cell wall of this protozoon, is expressed by both trophozoites and prezoosporangia (Montes et al. 2002).
Table 1. Perkinsus atlanticus. Labelling density with the serum against $P$. atlanticus trophozoites (PAT) expressed as number of gold particles (gp) per unit length or area in several cell compartments, from both trophozoites and prezoosporangia of $P$. atlanticus. Values are means \pm SEM obtained from measurements of at least 20 cells of each life-cycle form. Significance of differences between the mean values was evaluated using Student's $t$-test; ${ }^{* *} p<0.01$ and ${ }^{* * *} \mathrm{p}<0.001$ when comparing values in homologous compartments from both $P$. atlanticus life-cycle forms

\begin{tabular}{|lcc|}
\hline & Trophozoite & Prezoosporangium \\
\hline Cell wall $\left(\mathrm{gp} \mathrm{\mu m}^{-2}\right)$ & $34.25 \pm 4.27$ & $199.59 \pm 13.71^{* * *}$ \\
Plasma membrane $\left(\mathrm{gp} \mu \mathrm{m}^{-1}\right)$ & $7.07 \pm 1.13$ & $71.24 \pm 9.88^{* * *}$ \\
Lomasomes $\left(\mathrm{gp} \mu \mathrm{m}^{-2}\right)$ & $29.18 \pm 2.67$ & $2015.82 \pm 80.944^{* *}$ \\
Vacuolar membrane $\left(\mathrm{gp} \mu \mathrm{m}^{-1}\right)$ & $4.53 \pm 0.64$ & $3.13 \pm 0.91$ \\
Nucleolus $\left(\mathrm{gp} \mathrm{m}^{-2}\right)$ & $745.81 \pm 57.04$ & $1460.00 \pm 157.52^{* *}$ \\
Nucleoplasm $\left({\left.\mathrm{gp} \mu \mathrm{m}^{-2}\right)}^{2}\right)$ & $275.33 \pm 25.85$ & $353.63 \pm 28.15$ \\
\hline
\end{tabular}
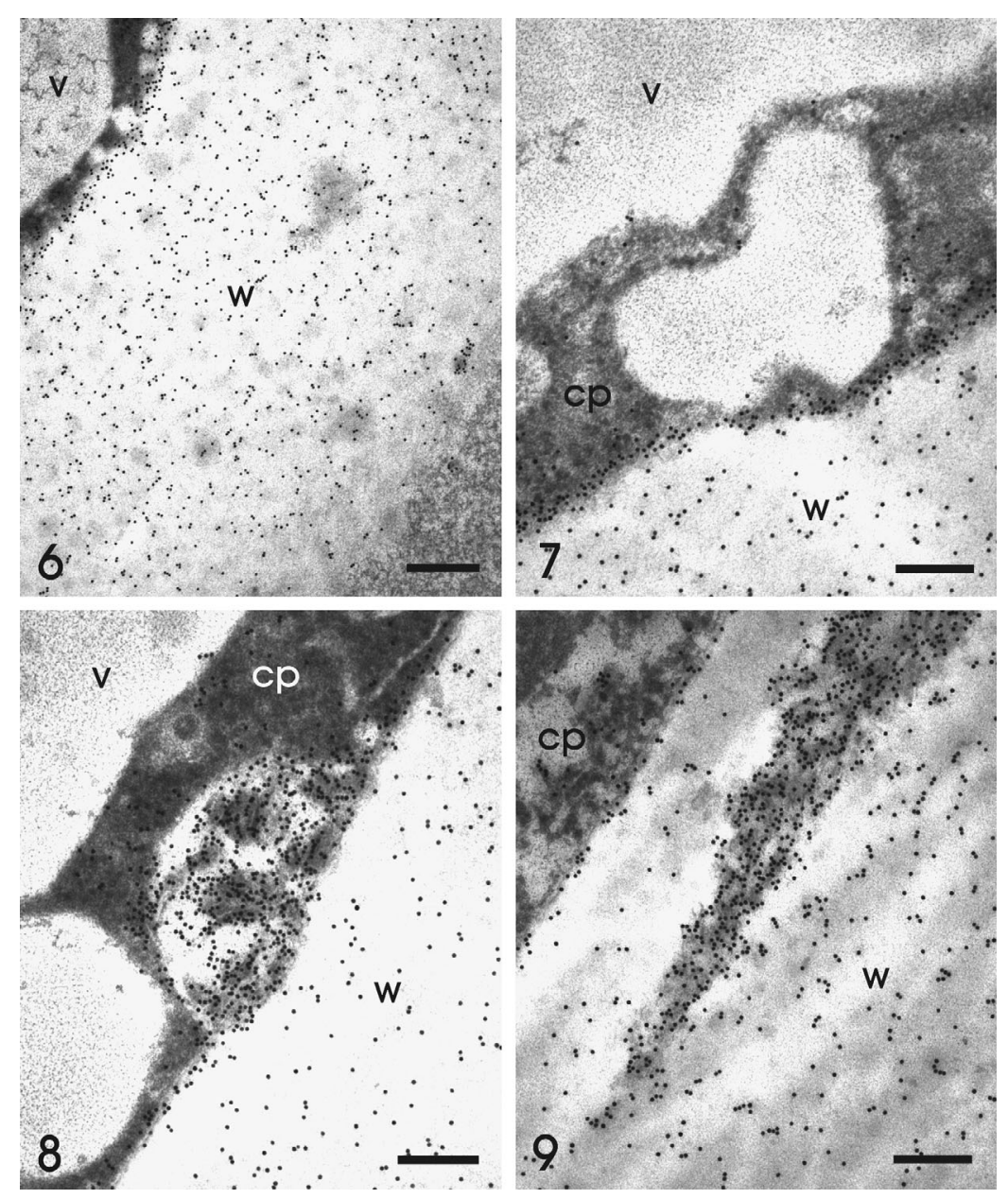

Figs. 6 to 9. Perkinsus atlanticus. Immunogold staining of prezoosporangium structures that react with the serum against PAT. Fig. 6. Immunoreactivity of the cell wall $(\mathrm{w})$ is strong and homogeneous. $\mathrm{v}=\overline{\text { vacuole; }}$ scale bar $=0.3 \mu \mathrm{m}$. Fig. 7. Higher magnification view of the plasma membrane showing extensive immunostaining. $\mathrm{cp}=$ cytoplasm; $\mathrm{v}=$ vacuole $; \mathrm{w}=$ cell wall $;$ scale bar $=0.2 \mu \mathrm{m}$. Fig. 8. Detail of a strongly labelled lomasome located in a cavity formed by an invagination of the plasma membrane. $\mathrm{cp}=$ cytoplasm $; \mathrm{v}=$ vacuole $; \mathrm{w}=$ cell wall; scale bar $=0.2 \mu \mathrm{m}$. Fig. 9. A lomasome embedded in the cell wall (w) external to the line of the plasmalemma also shows strong immunostaining. $\mathrm{cp}=$ cytoplasm; scale bar $=0.2 \mu \mathrm{m}$ 
Analysis of the resultant immunogold staining pattern revealed that Perkinsus atlanticus trophozoite to prezoosporangium differentiation is also accompanied by significant qualitative and quantitative changes in the ultrastructural distribution of the immunodominant antigens shared by these 2 developmental stages. Indeed, whereas the most immunoreactive subcellular structure in trophozoites was the granular component of the nucleolus, that of the prezoosporangia was the lomasome. Furthermore, when comparing labelling densities in homologous compartments of both $P$. atlanticus life-cycle forms, significant differences were detected in the nucleolus, cell wall, plasma membrane and lomasomes. Given that the highest intensity of labelling always corresponded to the prezoosporangium stage, our observations strongly suggest that $P$. atlanticus trophozoite to prezoosporangium differentiation results in the upregulation of the expression levels of some of the shared antigenic determinants.

One of the most prominent structures of trophozoites and prezoosporangia of Perkinsus species is the nucleolus, in which granular and fibrillar components have been identified (Azevedo 1989, Sagristà et al. 1996, Sunila et al. 2001). As for nucleolar immunoreactivity, we found that whereas the granular component was one of the most intensively labelled subcellular structures of $P$. atlanticus cells, the fibrillar areas were devoid of labelling. These findings, together with the fact that cytoplasmic ribosomes were essentially free of immunoreactivity, strongly suggest that nonribosomal proteins, such as ribonucleoproteins involved in RNA processing, are the immunoreactive molecules here. Furthermore, the strong labelling exhibited by this nucleolar subcompartment is consistent with this hypothesis, since several studies have shown that these ribonucleoproteins are highly immunogenic antigens (Welting et al. 2003).

A striking finding of the present study is that the main antigenic compartment of Perkinsus atlanticus, considering both developmental stages, was the lomasome of the prezoosporangium. Lomasomes have been described in several Perkinsus species (Perkins 1969, Sagristà et al. 1996, McLaughlin et al. 2000, Sunila et al. 2001) and seem to be structures common to walled eukaryotic cells. However, in spite of their universality, both the origin and function of this membranous complex remain matters of controversy. Whereas several authors have suggested that lomasomes, originating from either the Golgi apparatus, endoplasmic reticulum or plasmalemma, are involved in cell wall formation (Wilsenach \& Kessel 1965, Bussel \& Sommer 1973, Tanaka et al. 1984), others have considered lomasomes to be the result of unbalanced synthesis of the plasma membrane and cell wall, and no function is attributed to them (Heath \& Greenwood 1970). Irrespective of their function, our data are consistent with the hypothesis that lomasomes arise from the plasma membrane.

Indeed, the only membranous compartment that, during Perkinsus atlanticus trophozoite to prezoosporangium differentiation, exhibited an increase in its labelling density comparable to that observed in lomasomes was the plasma membrane. If, as seems likely, $P$. atlanticus lomasomes are derived from the plasma membrane, the high accumulation of antibody-binding sites in the lomasomes of the prezoosporangium strongly suggests that an active recruitment of plasma membrane antigens into lomasome membranes occurs during transition to the prezoosporangium life stage. In this regard, it is interesting to note that clearance of obsolete plasma membrane proteins by means of small membrane vesicles secreted into the extracellular space has been described in differentiating cells (Denzer et al. 2000). Both the high accumulation of antibody-binding sites in prezoosporangium lomasomes and the presence of lomasomes embedded in the prezoosporangium wall external to the line of the plasmalemma seem to support the notion that lomasomes may represent a mechanism for externalizing obsolete plasma membrane proteins in differentiating Perkinsus cells.

In conclusion, we have demonstrated that several antibody-binding epitopes, which are mainly located in the granular component of the nucleolus, chromatin, cell wall and plasma membrane, are conserved during Perkinsus atlanticus differentiation from the trophozoite to the prezoosporangium stage. Likewise, our findings show that the expression of several of the shared antigenic determinants is up-regulated during prezoosporangium formation.

Acknowledgements. The authors are grateful to A. Villalba (Centro de Investigacións Mariñas) for advice on the trophozoite purification experiments. We also thank A. García and the staff of Serveis Científico-Tècnics (Universitat de Barcelona) for technical assistance, and R. Rycroft for linguistic advice. This study was supported by a research grant from the CIRIT (Comissió Interdepartamental de Recerca i Innovació Tecnològica), Generalitat de Catalunya.

\section{LITERATURE CITED}

Auzoux-Bordenave S, Vigario AM, Ruano F, Domart-Coulon I, Doumenc D (1995) In vitro sporulation of the clam pathogen Perkinsus atlanticus (Apicomplexa, Perkinsea) under various environmental conditions. J Shellfish Res $14: 469-475$

Azevedo C (1989) Fine structure of Perkinsus atlanticus n. sp. (Apicomplexa, Perkinsea) parasite of the clam Ruditapes decussatus from Portugal. J Parasitol 75:627-635

Blackbourn J, Bower SM, Meyer GR (1998) Perkinsus qugwadi sp. nov. (incertae sedis), a pathogenic protozoan parasite of Japanese scallops, Patinopecten yessoensis, cultured in British Columbia, Canada. Can J Zool 76:942-953 
Bussel J, Sommer NF (1973) Lomasome development in Rhizopus stolonifer sporangiospores during anaerobiosis. Can J Microbiol 19:905-907

Casas SM, La Peyre JF, Reece KS, Azevedo C, Villalba A (2002) Continuous in vitro culture of the carpet shell clam Tapes decussatus protozoan parasite Perkinsus atlanticus. Dis Aquat Org 52:217-231

Casas SM, Grau A, Reece KS, Apakupakul K, Azevedo C, Villalba A (2004) Perkinsus mediterraneus n. sp., a protistan parasite of the European flat oyster Ostrea edulis from the Balearic Islands, Mediterranean Sea. Dis Aquat Org 58:231-244

Choi KS, Lewis DH, Powell EN, Frelier PF, Ray SM (1991) A polyclonal antibody developed from Perkinsus marinus hypnospores fails to cross react with other life stages of $P$. marinus in oyster (Crassostrea virginica) tissues. J Shellfish Res 10:411-415

Comps M, Chagot D (1987) Une parasitose nouvelle chez la Palourde Ruditapes decussatus L. C R Acad Sci Sér III Sci Vie 304:41-44

Coss CA, Robledo JAF, Ruiz GM, Vasta GR (2001) Description of Perkinsus andrewsi n. sp. isolated from the Baltic clam (Macoma balthica) by characterization of the ribosomal RNA locus, and development of a species-specific PCRbased diagnostic assay. J Eukaryot Microbiol 48:52-61

Da Ros L, Canzonier WJ (1985) Perkinsus, a protistan threat to bivalve culture in the Mediterranean basin. Bull Eur Assoc Fish Pathol 5:23-27

Denzer K, Kleijmeer MJ, Heijnen HFG, Stoorvogel W, Geuze HJ (2000) Exosome: from internal vesicle of the multivesicular body to intercellular signaling device. J Cell Sci 113:3365-3374

Dungan CF, Roberson BS (1993) Binding specificities of mono- and polyclonal antibodies to the protozoan oyster pathogen Perkinsus marinus. Dis Aquat Org 15:9-22

Figueras A, Robledo JAF, Novoa B (1992) Occurrence of haplosporidian and Perkinsus-like infections in carpetshell clams, Ruditapes decussatus (Linnaeus, 1758), of the Ría de Vigo (Galicia, NW Spain). J Shellfish Res 11: $377-382$

Gauthier JD, Vasta GR (1995) In vitro culture of the eastern oyster parasite Perkinsus marinus: optimization of the methodology. J Invertebr Pathol 66:156-168

Griffiths G, Hoppeler H (1986) Quantitation in immunocytochemistry: correlation of immunogold labeling to absolute number of membrane antigens. J Histochem Cytochem 34:1389-1398

Heath IB, Greenwood AD (1970) The structure and formation of lomasomes. J Gen Microbiol 62:129-137

Leander BS, Keeling PJ (2004) Early evolutionary history of dinoflagellates and apicomplexans (Alveolata) as inferred from hsp90 and actin phylogenies. J Phycol 40:341-350

Lee MK, Cho BY, Lee SJ, Kang JY, Jeong HD, Huh SH, Huh MD (2001) Histopathological lesions of Manila clam, Tapes philippinarum, from Hadong and Namhae coastal areas of Korea. Aquaculture 201:199-209

Lester RJG, Davis GHG (1981) A new Perkinsus species (Apicomplexa, Perkinsea) from the abalone Haliotis ruber. J Invertebr Pathol 37:181-187

Levine ND (1978) Perkinsus gen. n. and other new taxa in the protozoan phylum Apicomplexa. J Parasitol 64:549

López C, Carballal MJ, Azevedo C, Villalba A (1997) Differential phagocytic ability of the circulating haemocyte types of the carpet shell clam Ruditapes decussatus (Mollusca: Bivalvia). Dis Aquat Org 30:209-215

Mackin JG, Owen HM, Collier A (1950) Preliminary note on the occurrence of a new protistan parasite, Dermocystid- ium marinum n. sp. in Crassostrea virginica (Gmelin). Science 111:328-329

McLaughlin SM, Tall BD, Shaheen A, Elsayed EE, Faisal M (2000) Zoosporulation of a new Perkinsus species isolated from the gills of the softshell clam Mya arenaria. Parasite $7: 115-122$

Montes JF, Durfort M, García-Valero J (1995) Characterization and localization of an Mr $225 \mathrm{kDa}$ polypeptide specifically involved in the defence mechanisms of the clam Tapes semidecussatus. Cell Tissue Res 280:27-37

Montes JF, Estrada G, López-Tejero MD, García-Valero J (1996) Changes in the enterocyte cytoskeleton in newborn rats exposed to ethanol in utero. Gut 38:846-852

Montes JF, Durfort M, Lladó A, García-Valero J (2002) Characterization and immunolocalization of a main proteinaceous component of the cell wall of the protozoan parasite Perkinsus atlanticus. Parasitology 124:477-484

Norén F, Moestrup Ø, Rehnstam-Holm AS (1999) Parvilucifera infectans Norén et Moestrup gen. et sp. nov. (Perkinsozoa phylum nov.): a parasitic flagellate capable of killing toxic microalgae. Eur J Protistol 35:233-254

Park KI, Choi KS (2001) Spatial distribution of the protozoan parasite Perkinsus sp. found in the Manila clams, Ruditapes philippinarum, in Korea. Aquaculture 203: 9-22

Perkins FO (1969) Ultrastructure of vegetative stages in Labyrinthomyxa marina (=Dermocystidium marinum), a commercially significant oyster pathogen. J Invertebr Pathol 13:199-222

Romestand B, Torreilles J, Roch P (2001) Production of monoclonal antibodies against the Protozoa, Perkinsus marinus: estimation of parasite multiplication in vitro. Aquat Living Resour 14:351-357

Sagristà E, Durfort M, Azevedo C (1991) Ultrastructural study of the life cycle of Perkinsus sp. (phylum Apicomplexa), parasite of a Mediterranean clam. Coloq Franco-Ibérico Microsc Elec 1:145-146

Sagristà E, Durfort M, Azevedo C (1996) Ultrastructural data on the life cycle of the parasite, Perkinsus atlanticus (Apicomplexa), on the clam, Ruditapes philippinarum, in the Mediterranean. Sci Mar 60:283-288

Saldarriaga JF, McEwan ML, Fast NM, Taylor FJR, Keeling PJ (2003) Multiple protein phylogenies show that Oxyrrhis marina and Perkinsus marinus are early branches of the dinoflagellate lineage. Int $\mathrm{J}$ Syst Evol Microbiol 53: 355-365

Santmartí MM, García-Valero J, Montes JF, Pech A, Durfort M (1995) Seguimiento del protozoo Perkinsus sp., en las poblaciones de Tapes decussatus y Tapes semidecussatus del Delta del Ebro. Actas V Congreso Nac Acuicult 5:260-265

Siddall ME, Reece KS, Graves JE, Burreson EM (1997) 'Total evidence' refutes the inclusion of Perkinsus species in the phylum Apicomplexa. Parasitology 115:165-176

Sunila I, Hamilton RM, Dungan CF (2001) Ultrastructural characteristics of the in vitro cell cycle of the protozoan pathogen of oysters, Perkinsus marinus. J Eukaryot Microbiol 48:348-361

Tanaka S, Watanabe S, Maeda T (1984) Histochemical localization of thiamine pyrophosphatase in the lomasomes in asci of Arthroderma vanbreuseghemii. Sabouraudia 22:159-161

Villalba A, López MC, Carballal MJ (1993) Parásitos y alteraciones patológicas de tres especies de almeja, Ruditapes decussatus, Venerupis pullastra, y Venerupis rhomboides, en las rías gallegas. Actas IV Congreso Nac Acuicult 4:551-556 
Villalba A, Reece KS, Ordás MC, Casas SM, Figueras A (2004) Perkinsosis in molluscs: a review. Aquat Living Resour 17:411-432

Weibel ER (1979) Stereological methods, Vol 1. Academic Press, New York

Editorial responsibility: Albert Sparks,

Seattle, Washington, USA
Welting TJ, Raijmakers R, Pruijin GJ (2003) Autoantigenicity of nucleolar complexes. Autoimmun Rev 2:313-321

Wilsenach R, Kessel M (1965) The role of lomasomes in wall formation in Penicillium vermiculatum. J Gen Microbiol 40:401-404

Submitted: September 18, 2004; Accepted: February 5, 2005

Proofs received from author(s): July 20, 2005 